\title{
MULTIFORMIDADE E PEJOTIZAÇÃO: (RE)CONFIGURAÇÕES DO TRABALHO DOCENTE NO ENSINO SUPERIOR PRIVADO SOB O CAPITALISMO FLEXÍVEL ${ }^{1}$
}

\author{
Catia Eli Gemelli ${ }^{2}$ \\ Lisiane Quadrado Closs ${ }^{3}$ \\ Aline Mendonça Fraga ${ }^{4}$
}

http://dx.doi.org/10.1590/1413-2311.289.101464

\section{RESUMO}

O sistema capitalista apresenta especificidades nas diferentes demarcações temporais ao longo do seu transcurso histórico. As transformações políticas, econômicas e sociais vivenciadas contemporaneamente no Brasil impactam em mudanças nas relações de trabalho, que repercutem na profissão docente. Dado esse contexto, o objetivo deste trabalho foi analisar as atuais configurações de trabalho docente em instituições privadas de ensino superior, sobretudo da região metropolitana de Porto Alegre (RS). Trata-se de um estudo exploratório, de natureza qualitativa, baseado em entrevistas semiestruturadas realizadas com dez docentes da área de Administração. Evidencia-se, a partir dos relatos, a primazia do curto prazo, principalmente nas instituições de ensino cujas relações envolvem trabalho autônomo ou contratação por pessoa jurídica. A precarização das relações de trabalho e o discurso de gestão de si alcançam o trabalho docente e resultam em um movimento de pejotização. A flexibilidade e a volatidade revelam-se na exigência para que os/as docentes estejam sempre preparados/as a assumir diferentes disciplinas a fim de minimizar riscos de enfraquecimento

\footnotetext{
${ }^{1}$ Recebido em 30/3/2020, aceito em 11/8/2020.

2 Instituto Federal de Educação, Ciência e Tecnologia do Rio Grande do Sul; Osório - RS (Brasil); http://orcid.org/0000-0002-7163-0494, catia.gemelli@ osorio.ifrs.edu.br.

${ }^{3}$ Universidade Federal do Rio Grande do Sul - Programa de Pós Graduação em Administração; Porto Alegre RS (Brasil); https://orcid.org/0000-0003-1971-9341; lisiane.closs@ufrgs.br.

${ }^{4}$ Universidade Federal do Rio Grande do Sul - Programa de Pós Graduação em Administração; Porto Alegre RS (Brasil); http://orcid.org/0000-0002-4240-464X; alinemf.adm@ gmail.com.
} 
progressivo de seu vínculo com as IESs contratantes. No contexto do ensino superior privado, adaptabilidade, mobilidade e aceitação ao risco se sobressaem como condicionantes para o ingresso e a permanência na carreira docente.

Palavras-chave: Relações de Trabalho. Trabalho Docente. Capitalismo Flexível. Pejotização.

\section{MULTIFORMITY AND “PEJOTIZAÇÃO”: (RE) CONFIGURATIONS OF PROFESSORS' CAREER IN PRIVATE HIGHER EDUCATION UNDER FLEXIBLE CAPITALISM}

The capitalist system has specificities in different temporary demarcations throughout its historical course. Contemporary capitalism is based on volatility, meritocracy, flexibility, individuality and short-term goals. The new productive conditions drives the spread of the managerial ideology. The political, economic and social transformations experienced in Brazil also generated changes in work relations. The professor's career is not immune to these changes. Given this context, the objective of this paper is to analyze the work configurations documented in private institutions of higher education, mainly in the metropolitan region of Porto Alegre (RS). This is an exploratory study of qualitative nature based on semi-structured interviews conducted with ten professors from the business area. The reports evidenced the short-term relationship, self-employment work relations or being hired as a juridical person. The precarization of working relationships and the self-management discourse reach the teaching environment and result in a movement of "pejotização" - hiring workers as they were juridical persons. The flexibility and the volatility reveal that professors must be always prepared to assume different disciplines to minimize risks of weakening even more their relation with contracting organizations. In the context of private higher education, adaptability, mobility and risk acceptance stands out as conditions for entry and permanence in the teaching career.

Keywords: Labor Relations. Professors’ career. Flexible Capitalism. Pejotização.

\section{MULTIFORMIDAD Y “PEJOTIZAÇÃO”: (RE) CONFIGURACIONES DEL TRABAJO DOCENTE EN EDUCACIÓN SUPERIOR PRIVADA BAJO CAPITALISMO FLEXIBLE}


El sistema capitalista tiene especificidades en las diferentes demarcaciones temporales a lo largo de su curso histórico. Las transformaciones políticas, económicas y sociales experimentadas en Brasil también tienen un impacto en los cambios en las relaciones laborales y el trabajo docente no es inmune a estos cambios. Dado este contexto, el objetivo de este trabajo fue analizar las configuraciones actuales del trabajo docente en instituciones privadas de educación superior, especialmente en la región metropolitana de Porto Alegre (RS). Este es un estudio exploratorio, de naturaleza cualitativa, basado en entrevistas semiestructuradas realizadas con diez professores y professoras en el área de administración. A partir de los informes, se evidencia la primacía del corto plazo, principalmente en instituciones educativas cuyas relaciones involucran trabajo autónomo o contratación por parte de una entidad legal. La precariedad de las relaciones laborales y el discurso de autogestión alcanzan el trabajo docente y dan como resultado un movimiento de pejotização. La flexibilidad y la volatilidad se revelan en el requisito de que los maestros y las maestras siempre estén preparados para asumir diferentes disciplinas a fin de minimizar los riesgos de debilitar aún más su vínculo con las contratantes. En el contexto de la educación superior privada, la adaptabilidad, la movilidad y la aceptación del riesgo se destacan como condiciones de ingreso y permanencia en la carrera docente.

Palabras-clave: Relaciones Laborales. Trabajo Docente. Capitalismo Flexible. Pejotização.

\section{INTRODUÇÃO}

O capitalismo contemporâneo é, para Sennett (1999; 2006), um capitalismo flexível. Trata-se de um arquétipo desse sistema em que a volatilidade, a flexibilidade, a individualidade e a meritocracia imperam nas novas condições produtivas. O trabalho moderno possui, cada vez mais, uma natureza momentânea, na medida em que os empregos temporários ou de curto prazo substituem longas carreiras construídas em uma mesma instituição (SENNETT, 2015). Pode-se depreender daí que as pessoas estão se movimentando em um tempo transitório, inseridas em relações de trabalho e de formação meritocráticas, nas quais investem permanentemente em seu auto desenho (SILVA, 2015).

Compreende-se que os principais aspectos da configuração do capitalismo flexível são propulsores para o alastramento da ideologia gerencialista que, em sua essência, tem a empresa como centro do seu universo econômico, social e cultural. Em suas premissas, a 
empresa e suas necessidades proferem as prioridades e os valores sociais. A ênfase nos preceitos da gestão muda o próprio significado do trabalho e a forma como as pessoas visualizam as suas carreiras (GAULEJAC, 2007). O discurso gerencial preconiza que todos/as vivam em contínua superação, com flexibilidade e adaptabilidade para acompanhar as contínuas mudanças impostas pelo mercado (DARDOT; LAVAL, 2016). Nesse contexto, a competição se introjeta até na esfera da individualidade e a vida passa a ser vista como uma empresa na qual cada um/a assume a função de gestor/a.

Argumenta-se que a multiformidade das relações de trabalho, sob os aspectos jurídicos de contratação, é também um reflexo do paradigma da flexibilidade e do discurso gerencialista. No Brasil, desde a década de 1990, observam-se mudanças que são interpretadas como sintomas de tentativas de implementação de um novo sistema de relações do trabalho, que se caracteriza pela desregulamentação das normas legais (SOUZA, 2013). Ao analisarem as transformações políticas, econômicas e sociais vivenciadas nas relações de trabalho no Brasil, Alves (2009) e Antunes (2018) afirmam que há uma crescente precarização estrutural tanto no plano objetivo, quanto na subjetividade do trabalhador.

A atividade docente não ficou imune a todas essas transformações no mundo do trabalho e à concepção contemporânea de educação neoliberal (JESSOP; 2018; LAVAL, 2019), sendo impactada pelo surgimento de novas configurações de trabalho e pela modificação dos modelos existentes (MAUÉS; SOUZA, 2016; SEVERO; FLECK, 2017; LOCATELLI, 2017; BECHI, 2017). O processo discursivo em torno da gestão de si (GAULEJAC, 2007) afeta também docentes de ensino superior, como indicou a pesquisa de Orbem (2016). Segundo a autora, o Brasil vem vivenciando um crescente processo de pejotização docente, que é a constituição de uma pessoa jurídica para a prestação dos mesmos serviços antes realizados como trabalhador/a contratado/a em regime da CLT.

A expansão do setor privado mercantil na esfera educacional e a adoção da racionalidade neoliberal desencadearam fenômenos como a intensificação e a precarização do trabalho docente (BECHI, 2017). As evidências indicam que a profissão vem sendo significativamente afetada tanto por transformações mais amplas no mundo do trabalho quanto por mudanças na natureza do trabalho em si (NASCIMENTO; SALVÁ, 2013; PASSOS; FREITAS, 2015; IRIGARAY et al., 2019).

Diversos estudos (HYPOLITO, 2011; IVO; HYPOLITO, 2015; RIBEIRO; LEDA; SILVA, 2015; RIBEIRO; LEDA, 2016; SANTOS et al., 2016) com docentes de instituições públicas e privadas brasileiras identificaram reflexos da adesão das Instituições de Ensino 
Superior (IES) às premissas do modelo gerencial, tais como a intensificação do trabalho e o adoecimento. Esses resultados suscitam novos estudos sobre a (re)configuração do trabalho docente diante das velozes e das recentes mudanças nacionais e globais na legislação trabalhista e do avanço da racionalidade neoliberal sobre a educação, em escala mundial (GILDERSLEEVE, 2017; ROSS; SAVAGE; WATSON, 2019).

O último relatório do senso nacional da educação superior indica que o Brasil possui 384.474 professores/as de nível superior registrados/as, sendo 173.868 em instituições públicas (federais, estaduais e municipais) e 210.606 em instituições de ensino privadas. Em 2018, 3,4 milhões de estudantes ingressaram em cursos de educação superior de graduação. Desse total, 83,1\% em instituições privadas. As IES privadas têm uma participação de 75,4\% no total de matrículas de graduação, ou seja, a cada quatro estudantes matriculados/as no ensino superior brasileiro, três estão em instituições privadas. Ainda, no período compreendido entre 2008 e 2018, a rede privada cresceu 59,3\%, enquanto a rede pública aumentou apenas 7,9\% (INEP, 2019).

Outra característica da educação superior brasileira indicada pelo censo é o expressivo crescimento de cursos na modalidade de Educação à Distância (EAD). O número de ingressantes em cursos de graduação à distância tem crescido substancialmente nos últimos anos. Entre 2008 e 2018, o número de ingressos ampliou em 10,6\% nos cursos de graduação presencial e triplicou $(196,6 \%)$ nos cursos a distância. Enquanto a participação percentual de ingressantes em cursos de graduação a distância em 2008 era de 19,8\%, em 2018 passou para quase $40 \%$ (INEP, 2019).

Ademais, tem crescido a presença de grupos estrangeiros no ensino superior brasileiro. Originários, principalmente, dos Estados Unidos da América (EUA) e da Europa, tais grupos oferecem seus serviços com marcas internacionais sob o discurso de uma empregabilidade global. Um exemplo é o Laureate International Universities que está presente em 25 países e, atualmente, possui 12 IES no Brasil. Em 2018, esse conglomerado anunciou um processo de venda de suas universidades em Portugal para passar a investir com maior intensidade nos mercados considerados em expansão pelo grupo, visando principalmente Brasil, México, Chile e Peru (OBSERVADOR, 2018).

Considera-se que na contemporaneidade o trabalho docente de ensino superior em instituições privadas é afetado por uma dupla complexidade: a primeira, refere-se ao alastramento da racionalidade neoliberal, que altera o sentido social da educação e aproxima a docência da noção de prestação de serviços; a segunda, à precarização das relações 
trabalhistas provocada pela atual crise do capitalismo e por reformas político-econômicas. Diante disso, este estudo tem como objetivo analisar as atuais configurações de trabalho docente na área de Administração em instituições privadas, de ensino superior, da região metropolitana de Porto Alegre/RS.

\section{CAPITALISMO FLEXÍVEL, IDEOLOGIA GERENCIALISTA E EDUCAÇÃo NEOLIBERAL}

Entre as mudanças culturais e estruturais provocadas pelo capitalismo flexível estão o declínio do emprego estável e a gestão de grandes instituições, tais como o sistema de previdência e as escolas, funcionando como se fossem empresas (SENNETT, 2006). Seu discurso preconiza que, atacando a burocracia rígida e enfatizando o risco, a flexibilidade dá às pessoas mais liberdade para moldarem as suas vidas (SENNETT, 2006). Na esfera do trabalho, as mesmas mudanças buscam reinventar as instituições, para que o presente se torne descontínuo em relação ao passado (SENNETT, 1999). Promulga-se um ideal individual capaz de orientar-se no curto prazo, em contínuo desenvolvimento de habilidades potenciais e com grande disposição ao risco (SILVA, 2015).

A exaltação da flexibilidade, o discurso meritocrático pautado na individualidade e a primazia do curto prazo aliam-se às premissas da ideologia gerencialista, que se trata de um modelo de pensamento que legitima o lucro como finalidade. Desse modo, a empresa e suas necessidades proferem as prioridades, os valores e as imagens ideais da nova subjetividade (GAULEJAC, 2007) desenvolvendo uma nova representação do mundo e de cada pessoa, na qual a única forma evidente de autorrealização alicerça-se na lógica da produtividade. Assim sendo, a empresa transforma-se em uma referência para a construção de si (ROHM; LOPES, 2015). As convenções da ideologia gerencialista adentram as mais variadas esferas da sociedade por meio de um discurso gerencial, constituído por uma linguagem própria: a linguagem do management. Seu vocabulário econômico faz com que diferentes temas da instância coletiva sejam tratados a partir do enfoque da empresa (GAULEJAC, 2007), tais como a família, a religiosidade, a educação e o trabalho.

A ideia de empresa passa a ser entendida como modelo ideal, inclusive para a conduta individual, uma vez que representa um símbolo de eficácia e de iniciativas ousadas diante das adversidades (BENDASSOLLI, 2000). O convite para se tornar empreendedor ou empreendedora de sua própria vida, alicerçado ao empresariamento de si, dá origem ao 
conceito de Indivíduo S/A formulado por Gaulejac (2007). Sob essa concepção, de gestor/a de si, a pessoa deve entender-se como uma empresa, uma marca que precisa ser valorizada e sistematicamente atualizada. Desta forma, a vida humana se torna um capital que convém tornar produtivo. A gestão das empresas e a gestão de si obedecem, assim, às mesmas leis: não basta ser rentável ou viável, é preciso estar na frente, do modo mais ativo, rápido e preciso (ITUASSU; TONELLI, 2014).

Assim como Sennett (2006) e Gaulejac (2007) afirmam que as injunções do paradigma gestionário se alastram para os mais diversos espaços, Dardot e Laval (2016) entendem que a razão neoliberal é global, não apenas porque é mundial, mas também porque não se limita à esfera econômica, uma vez que atravessa e modifica todas as dimensões da vida humana. Dessa forma, o neoliberalismo impõe a lógica da concorrência do mercado e as injunções do mundo corporativo como princípios universais (ANDRADE; OTA, 2015). A racionalidade neoliberal representa uma lógica normativa que naturaliza a concorrência e o modelo de empresa, uma lógica de mercado que se alastra rapidamente para as outras dimensões da vida (DARDOT; LAVAL, 2016).

Sob essa racionalidade, a educação contemporânea ocidental tornou-se uma educação neoliberal, isto é: "um determinado modelo escolar que considera a educação como um bem essencialmente privado e cujo valor é, antes de tudo, econômico" (LAVAL, 2019, p. 17). Essa perspectiva altera o foco dos segmentos educacionais que, de uma forma tênue ou declarada, centram-se no desenvolvimento de habilidades de trabalho (KALFA; TAKSA, 2017). O objetivo do modelo de educação neoliberal é a formação profissional que, potencializada pela educação, forneça condições de responder positivamente à racionalidade de mercado por suas características de diferenciação competitiva, ligadas, por sua vez, à inovação, ao empreendedorismo, à criatividade, à eficiência e à flexibilidade (PENSIN, 2018).

A reestruturação produtiva do capital, tanto dos países líderes em desenvolvimento quanto dos países emergentes, impõe novas determinações ao campo educacional, em especial ao ensino superior, conferindo-lhe novos papéis. Diante disso, ocorrem profundas modificações no contexto desse nível de ensino, geradas por sua aproximação com o processo produtivo capitalista (FERRER; ROSSIGNOLI, 2016). Quando a profusão da ideologia gerencialista é percebida também nos espaços educacionais, a formação humana torna-se uma produção para o trabalho e o sistema educacional que, permeado pela racionalidade do capital, reproduz em suas práticas as premissas do modelo empresarial (GEMELLI, 2020). 
Sob esse modelo educacional, o trabalho docente no ensino superior é diretamente afetado. As novas exigências educacionais alinhadas ao mercado se introjetam nos discursos sobre a função do trabalho docente. Outrossim, as mudanças nas relações de trabalho também são percebidas nas IEs privadas, e a carreira docente modifica-se perante os paradigmas da flexibilidade. O próximo capítulo discute o trabalho docente no ensino superior sob o axioma gerencial.

\section{TRABALHO DOCENTE NO ENSINO SUPERIOR}

O contexto da educação superior brasileira configurou-se em um cenário altamente mercantilizado, heterogêneo e diversificado a partir dos anos 1990 (CALDERÓN, 2013). As instituições de ensino, independentemente de sua modalidade (ensino fundamental, médio ou superior), revelam um cotidiano cada vez mais atravessado por uma racionalidade instrumental e mercadológica. Assim, agrega-se ao trabalho docente novas responsabilizações que utilizam a linguagem do management, tais como avaliação de resultados, cumprimento de metas e otimização de espaços físicos (RIBEIRO; LEDA; SILVA, 2015). Quando as premissas do gerencialismo são aplicadas ao ensino e à pesquisa, a essência da produção e divulgação do conhecimento se altera. A inserção da lógica gerencial no meio educacional passa a impor um "ethos" corporativo para um tipo de atividade que pouco ou nada tem a ver com o mundo das empresas (ALCADIPANI, 2011).

Estudos anteriores (HYPOLITO, 2011; JEFFREY, 2012; RIBEIRO; LEDA; SILVA, 2015; IVO; HYPOLITO, 2015; RIBEIRO; LEDA, 2016; ANDERSON, 2017; PENSIN, 2018) analisaram os efeitos dos paradigmas gerencialistas e da adoção do discurso permeado pela lógica empresarial sobre o trabalho docente. Ribeiro e Leda (2016) observaram um aumento progressivo na demanda e na diversidade de trabalho para atender uma cultura acadêmica cada vez mais atrelada a princípios de flexibilidade, de empreendedorismo e de autossuperação. A racionalidade instrumental, pragmática e gerencialista que predomina nos novos modelos de universidade é vista pelos seus defensores como eficaz, inclusiva e democratizante; e pelos seus críticos, geradora de trabalho intensificado e precário (RIBEIRO; LEDA; SILVA, 2015).

Fatores tais como mudanças nas formas de contratação e crescimento do desemprego evidenciam a complexificação das relações de trabalho no ensino superior, em um processo crescente de individualização de docentes que culminam em fragilização social (SOUZA, 
2013). A intensificação e a precarização do trabalho, somadas ao sofrimento causado pelas dimensões afetivas, éticas e políticas, em contraponto com as premissas da lógica mercadológica, podem resultar no adoecimento de professores e professoras. Os resultados das pesquisas de Hypolito (2011), Ivo e Hypolito (2015), Ribeiro, Leda e Silva (2015), Santos et al. (2016) e Ribeiro e Leda (2016) demonstram o adoecimento docente como um dos reflexos da adesão das instituições de ensino às premissas do modelo gerencial.

No campo da Administração, a pesquisa de Souza-Silva e Davel (2015) sobre a formação de professores/as dessa área, no Brasil, identificou que a lógica de muitas organizações privadas de ensino superior baseava-se em um modelo empresarial/comercial de lucratividade de curto prazo. Na percepção dos/as professores/as entrevistados/as, tal modelo interfere na qualidade do ensino e na profissionalidade docente, pois impede que grande parte das organizações de ensino superior alcance o principal objetivo educacional defendido pelos autores: a formação discente crítica e reflexiva.

Souza-Silva e Davel (2015), Calderón (2013) e Ferrer e Rossignoli (2016) destacam ainda que o tipo de contrato de trabalho que as organizações de ensino superior privadas oferecem para os/as docentes é um importante fator socioeconômico e profissional. O regime de trabalho pelo qual ocorrem os contratos impacta não apenas nos aspectos financeiros da carreira, como também nas suas dimensões motivacionais. O modelo contratual precarizado gera um sentimento ambíguo: "De um lado, o prazer de trabalhar em sala de aula; de outro, desânimo, desmotivação, desvalorização e precarização da função docente" (CALDERÓN, 2013, p. 492).

Diante desse cenário, é relevante conhecer a perspectiva jurídica da terceirização e da flexibilização dos contratos de trabalho, incluindo um breve panorama histórico da legislação brasileira. As diferentes formas de contratação previstas na Consolidação das Leis de Trabalho (CLT) definem as possibilidades de regimes de trabalho de diferentes categorias, entre elas a da carreira docente.

\section{TERCEIRIZAÇÃO E FLEXIBILIZAÇÃO NAS RELAÇÕES DE TRABALHO}

De acordo com estudo publicado em 2017 pela Organização Internacional do Trabalho (OIT), foram realizadas reformas legislativas laborais e de mercado de trabalho em 110 países entre 2008 e 2014. As mudanças legais nas normas trabalhistas são, portanto, um movimento global. No Brasil, desde 2016, intensificou-se o discurso de que os direitos e as garantias 
sociais da classe trabalhadora são um obstáculo à superação da crise econômica brasileira (GUIMARÃES JUNIOR; SILVA, 2020).

A terceirização, por exemplo, é um dos produtos provenientes dessas transformações ocorridas no sistema capitalista que impactaram o mercado de trabalho. Trata-se de uma forma de contratação que se adequa, principalmente, aos interesses da política neoliberal (FILGUEIRAS; CAVALCANTE, 2015). O movimento pode ter se intensificado após a publicação da Lei 13.429/2017, que altera dispositivos da Lei 6.019, de 3 de janeiro de 1974. A lei modifica as regras para trabalho temporário e para contratação de prestadores de serviços, inclusive, mediante terceirização ou quarteirização da atividade-fim.

A terceirização foi a principal forma de flexibilização dos contratos de trabalho a contar da década de 90. Conforme Souza (2013), ela se expressa sob diferentes formas: subcontratação de empresas de prestação de serviços de apoio e ou cooperativas, alocação de trabalho temporário ou contratação de pessoa jurídica ou autônoma. Ainda de acordo com a autora, a terceirização expressa a busca pela redução dos custos e, embora se apresente de diferentes formas, contribui diretamente para a precarização das relações de trabalho.

No Brasil, por um longo período histórico, a terceirização foi considerada ilegal. A primeira súmula que tratou do tema da terceirização no Brasil foi o Enunciado 256 do TST, do ano de 1986, com a seguinte redação:

\footnotetext{
Salvo os casos de trabalho temporário e de serviço de vigilância, previstos nas Leis $\mathrm{N}^{\circ}$ 6.019/74 e $\mathrm{N}^{\circ} 7.102 / 83$, é ilegal a contratação de trabalhadores por empresa interposta, formando-se o vínculo empregatício diretamente com o tomador dos serviços.
}

Em dezembro de 1993, já esteada na Constituição Federal de 1988, a Súmula 256 foi revista e ampliada, transformando-se na Súmula 331 do TST, que declarava:

\begin{abstract}
A contratação de trabalhadores por empresa interposta é ilegal, formando-se o vínculo diretamente com o tomador dos serviços, salvo no caso de trabalho temporário (Lei $\mathrm{N}^{\circ}$ 6.019/74). II - A contratação irregular de trabalhador, mediante empresa interposta, não gera vínculo de emprego com os órgãos da Administração Pública direta, indireta ou fundacional (art. 37, II, da Constituição Federal de 1988). III - Não forma vínculo de emprego com o tomador a contratação de serviços de vigilância (Lei $\mathrm{N}^{\circ}$ 7.102/83) e de conservação e limpeza, bem como a de serviços especializados ligados à atividade-meio do tomador, desde que inexistente a pessoalidade e a subordinação direta. IV - O inadimplemento das obrigações trabalhistas, por parte do empregador, implica a responsabilidade subsidiária do tomador dos serviços quanto àquelas obrigações, desde que haja participado da relação processual e conste também do título executivo judicial.
\end{abstract}

Desde a alteração da súmula em 1993 até o ano de 2017, a terceirização não foi modificada. Em novembro de 2017 houve a publicação da Lei n ${ }^{\circ} 13.467 / 17$ que alterou mais 
de cem artigos da CLT e passou a ser conhecida como reforma trabalhista, abrangendo também os contratos de prestação de serviços terceirizados. Em sua análise crítica à reforma, Krein e Colombi (2019) definem que sua sustentação se baseia no tripé: flexibilização das relações de trabalho; fragilização das instituições de proteção; e individualização dos riscos. Dessa forma, o autor e a autora sinalizam que a terceirização contribui para o aumento da vulnerabilidade social nas relações de trabalho.

Em março de 2017 foi aprovada a Lei $n^{\circ} 13.429$ que regulamentou o trabalho temporário e a prestação de serviços das empresas prestadoras de serviços terceirizados. Por fim, em agosto de 2018, o Supremo Tribunal Federal julgou a terceirização e decidiu que é válida e regularmente contratada a terceirização de "atividade fim" da empresa, ou seja, permitiu a utilização da terceirização irrestrita e abriu precedentes para a quarteirização. A quarteirização, antes não prevista na legislação brasileira, refere-se à inclusão de uma quarta figura no processo de contratação, responsável pela administração dos serviços que foram terceirizados (FONTOURA; FONTOURA, 2017). A redação do art. 4º da lei 6.019/64, alterada pela lei 13.429/17, incluiu no texto da reforma a expressão "atividade principal", estabelecendo que:

Considera-se prestação de serviços a terceiros a transferência feita pela contratante da execução de quaisquer de suas atividades, inclusive sua atividade principal, à pessoa jurídica de direito privado prestadora de serviços que possua capacidade econômica compatível com a sua execução.

No que se refere ao exercício de atividade profissional remunerada, a legislação brasileira prevê o trabalho autônomo, a contratação com carteira de trabalho assinada regida pela CLT e a prestação de serviços por pessoa jurídica. O/A trabalhador/a autônomo/a é definido/a pelo artigo $4^{\circ}$ da Lei ${ }^{\circ} 5.890 / 73$ como:

O que exerce habitualmente, e por conta própria, atividade profissional remunerada; o que presta serviços a diversas empresas, agrupado ou não em sindicato, inclusive os estivadores, conferentes e assemelhados; o que presta, sem relação de emprego, serviço de caráter eventual a uma ou mais empresas; o que presta serviço remunerado mediante recibo, em caráter eventual, seja qual for a duração da tarefa.

O Recibo de Pagamento de Autônomo (RPA) é o documento emitido para formalizar o vínculo entre um/a prestador/a de serviço (profissional autônomo/a) e um/a tomador/a de serviço (empresa/contratante). Normalmente, é emitido pela parte contratante, ou seja, quem irá pagar pelo serviço de um/a profissional que não seja vinculado/a à Consolidação das Leis de Trabalho (CLT). 
A contratação com a assinatura da carteira de trabalho pode ser como mensalista com carga horária de trabalho e salário mensal determinado - e como horista. O/A trabalhador/a horista, de acordo com a CLT (Art. 58-A e $\S \S 3^{\circ}, 4^{\circ}, 5^{\circ}, 6^{\circ}$ e $7^{\circ}$ ), é aquele/a que recebe o salário mensalmente, porém determinado pelo valor-hora. Esse/Essa profissional tem todos os direitos e obrigações dos/as demais empregados/as, com algumas peculiaridades, como, por exemplo, pagamento do repouso semanal remunerado em separado do valor das horas trabalhadas; rendimento mensal variável de acordo com os dias do mês; cálculo da remuneração de férias, $13^{\circ}$ salário e aviso prévio indenizado a partir das médias de horas trabalhadas.

Por fim, a pejotização é uma forma de terceirização em que o/a trabalhador/a, pessoa física, presta o serviço em uma empresa através da constituição de uma pessoa jurídica, utilizando um contrato de prestação de serviços de natureza civil, sem a incidência de qualquer direito trabalhista. Trata-se se de uma modalidade de externalização das atividades na qual, para que haja a contratação ou a manutenção do posto de trabalho, a empresa contratante exige do/a trabalhador/a, pessoa física, que este/a constitua uma pessoa jurídica (ORBEM, 2016).

Para fins de evitar a pejotização indiscriminada, de forma a substituir um/a trabalhador/a com carteira assinada por outro/a, contratado/a como pessoa jurídica ou prestador/a de serviços sem vínculo empregatício, o artigo $5^{\circ} \mathrm{C}$ da Lei 13.467/2017 estabelece que o/a empregado/a demitido/a não poderá prestar serviços para o/a mesmo/a empregador/a, na condição de PJ, antes do decurso de 18 meses a contar da data de seu efetivo desligamento.

\section{PROCEDIMENTOS METODOLÓGICOS}

O presente estudo é exploratório, de natureza qualitativa, e baseou-se em entrevistas semiestruturadas (GASKELL, 2015) realizadas com dez docentes da área de Administração. Os/as participantes lecionavam em cursos de graduação, MBAs e especializações em diferentes instituições privadas de ensino superior e residiam e/ou ministravam aulas principalmente na região metropolitana de Porto Alegre/RS. As entrevistas ocorreram nos meses de janeiro, fevereiro e março de 2019. Como critérios para a seleção dos/as entrevistados/as, estabeleceu-se: estar ministrando aulas em uma instituição privada de ensino superior; ter sido contratado/a por pelo menos dois modelos jurídicos diferentes durante sua trajetória docente. 
O Quadro 1 apresenta o perfil dos/as entrevistados/as. Considerou-se como início da carreira docente o momento da primeira experiência remunerada em curso de nível técnico, superior ou pós-graduação em Administração, independente do regime jurídico de contratação.

Quadro 1: Perfil dos/as entrevistados/as

\begin{tabular}{|c|c|c|c|c|c|}
\hline & $\begin{array}{l}\text { Idade } \\
\text { Atual }\end{array}$ & $\begin{array}{c}\text { Tempo } \\
\text { de } \\
\text { Docência }\end{array}$ & $\begin{array}{l}\text { Nível de } \\
\text { Formação } \\
\text { Atual }\end{array}$ & $\begin{array}{l}\text { Formação no Início da } \\
\text { Carreira Docente }\end{array}$ & $\begin{array}{l}\text { Níveis de Ensino } \\
\text { em que já atuou }\end{array}$ \\
\hline Anna & 37 & 10 anos & $\begin{array}{c}\text { Doutoranda } \\
\text { em } \\
\text { Administração }\end{array}$ & $\begin{array}{l}\text { Graduação em } \\
\text { Administração }\end{array}$ & $\begin{array}{l}\text { Graduação e pós- } \\
\text { graduação lato } \\
\text { sensu }\end{array}$ \\
\hline Paulo & 48 & 6 anos & $\begin{array}{c}\text { Doutorando } \\
\text { em } \\
\text { Administração }\end{array}$ & $\begin{array}{c}\text { Graduação em } \\
\text { Jornalismo, MBA em } \\
\text { Finanças, MBA em } \\
\text { Marketing e cursando } \\
\text { Mestrado em } \\
\text { Administração. }\end{array}$ & $\begin{array}{c}\text { Graduação e pós- } \\
\text { graduação lato } \\
\text { sensu }\end{array}$ \\
\hline Fernando & 42 & 6 anos & $\begin{array}{c}\text { Doutorando } \\
\text { em } \\
\text { Administração }\end{array}$ & $\begin{array}{c}\text { Graduação e Mestrado em } \\
\text { Administração }\end{array}$ & $\begin{array}{l}\text { Graduação e pós- } \\
\text { graduação lato } \\
\text { sensu }\end{array}$ \\
\hline Manuel & 36 & 7 anos & $\begin{array}{c}\text { Doutor em } \\
\text { Administração }\end{array}$ & $\begin{array}{c}\text { Graduação em Psicologia } \\
\text { e Mestrado em } \\
\text { Administração } \\
\end{array}$ & $\begin{array}{l}\text { Graduação, pós- } \\
\text { graduação lato } \\
\text { sensu e mestrado }\end{array}$ \\
\hline Antonia & 46 & 6 anos & $\begin{array}{l}\text { Especialista } \\
\text { em } \\
\text { Comunicação } \\
\text { com o } \\
\text { Mercado }\end{array}$ & $\begin{array}{c}\text { Graduação em } \\
\text { Comunicação/ } \\
\text { Publicidade e Propaganda } \\
\text { e pós-graduação lato } \\
\text { sensu em Comunicação } \\
\text { com o Mercado }\end{array}$ & $\begin{array}{l}\text { Pós-graduação } \\
\text { lato sensu }\end{array}$ \\
\hline Luiz & 39 & 5 anos & $\begin{array}{c}\text { Doutor em } \\
\text { Administração }\end{array}$ & $\begin{array}{c}\text { Graduação em } \\
\text { Administração/Comércio } \\
\text { Exterior, MBA em } \\
\text { Finanças e MBA em } \\
\text { controladoria } \\
\end{array}$ & $\begin{array}{l}\text { Graduação, pós- } \\
\text { graduação lato } \\
\text { sensu e mestrado }\end{array}$ \\
\hline Norma & 39 & 5 anos & $\begin{array}{c}\text { Doutoranda } \\
\text { em } \\
\text { Administração }\end{array}$ & $\begin{array}{c}\text { Graduação em } \\
\text { Administração/Comércio } \\
\text { Exterior e MBA em } \\
\text { Liderança Coach }\end{array}$ & $\begin{array}{c}\text { Ensino técnico, } \\
\text { Graduação e pós- } \\
\text { graduação lato } \\
\text { sensu }\end{array}$ \\
\hline Vera & 39 & 7 anos & $\begin{array}{c}\text { Mestra em } \\
\text { Administração }\end{array}$ & $\begin{array}{c}\text { Graduação em } \\
\text { Administração e cursando } \\
\text { Mestrado }\end{array}$ & $\begin{array}{c}\text { Graduação e pós- } \\
\text { graduação lato } \\
\text { sensu }\end{array}$ \\
\hline Ruben & 37 & 12 anos & $\begin{array}{c}\text { Doutor em } \\
\text { Administração }\end{array}$ & $\begin{array}{c}\text { Graduação e Mestrado em } \\
\text { Administração }\end{array}$ & $\begin{array}{c}\text { Graduação e pós- } \\
\text { graduação lato } \\
\text { sensu }\end{array}$ \\
\hline Saul & 25 & 3 anos & $\begin{array}{l}\text { Especialista } \\
\text { em Direito do } \\
\text { Trabalho }\end{array}$ & $\begin{array}{l}\text { Graduação em Tecnologia } \\
\text { em Recursos Humanos e } \\
\text { pós-graduação lato sensu } \\
\text { em Direito do Trabalho }\end{array}$ & $\begin{array}{c}\text { Graduação e pós- } \\
\text { graduação lato } \\
\text { sensu }\end{array}$ \\
\hline
\end{tabular}


Nota: O perfil dos/as entrevistados/as foi elaborado pelas autoras com base nas entrevistas. Os nomes dos/as entrevistados/as foram alterados e substituídos por nomes coletados de um diário de classe do ano de 1961 da Faculdade de Ciências Econômicas da Universidade Federal do Rio Grande do Sul (UFRGS), que deu origem à atual Escola de Administração. A página do diário encontra-se no livro de Stahlhoefer (2016).

As entrevistas resultaram em 385 minutos de áudios transcritos e 64 laudas. Considerando os propósitos da pesquisa, as transcrições passaram por uma análise de conteúdo, na perspectiva qualitativa, a partir de Bauer (2015) e Minayo (2016). Como trajetória de análise, adotaram-se os procedimentos metodológicos orientados por Minayo (2016): categorização, inferência, descrição e interpretação. As categorias de análise que embasaram a realização das entrevistas, bem como os resultados e as discussões, foram elaboradas, a priori, a partir da literatura. Neste trabalho, a análise de conteúdo foi operacionalizada qualitativamente e sem a ajuda de softwares. Destaca-se que, para fins de confidencialidade, o nome das Instituições de Ensino foi omitido e substituído por um traço (--------) durante as citações dos trechos de entrevistas.

\section{ANÁLISE DOS RESULTADOS}

A análise dos resultados indicou a existência de quatro diferentes formas de contratação jurídica no ensino privado: celetista mensalista; celetista horista; constituição de Pessoa Jurídica (PJ) com pagamento por nota fiscal; e trabalho autônomo remunerado por Recibo de Pagamento Autônomo (RPA). Identificou-se, ainda, a contratação pública como professor/a substituto/a em IEs federais, sob o regime da Lei no 8.745/93. O Quadro 2 apresenta todos os regimes jurídicos de trabalho pelos quais os/as docentes foram contratados/as ao longo de sua trajetória, quais sejam: celetista mensalista, celetista horista, constituição de Pessoa Jurídica (PJ) com pagamento por nota fiscal, trabalho autônomo remunerado por Recibo de Pagamento Autônomo (RPA) e contrato temporário como professor/a substituto/a em IES públicas.

Quadro 2: Regimes jurídicos de trabalho e número de instituições

\begin{tabular}{c|c|c|c|c}
\hline & $\begin{array}{c}\text { Regime(s) } \\
\text { jurídico(s) de } \\
\text { contratação } \\
\text { atual }\end{array}$ & $\begin{array}{c}\text { Regimes jurídicos pelos } \\
\text { quais já foi contratado/a }\end{array}$ & $\begin{array}{c}\text { Máximo de IESs } \\
\text { com vínculo } \\
\text { simultâneo }\end{array}$ & $\begin{array}{c}\mathbf{N}^{0} \text { de IESs } \\
\text { em que já } \\
\text { lecionou }\end{array}$ \\
\hline Anna & $\begin{array}{c}\text { CLT mensalista } \\
20 \mathrm{~h}\end{array}$ & $\begin{array}{c}\text { CLT horista, CLT } \\
\text { mensalista, Contrato } \\
\text { temporário (Lei no } 8.745 / 93), \\
\text { Autônoma (RPA) }\end{array}$ & 1 & 5 \\
\hline
\end{tabular}

(c) $(1) \Theta 2$ REAd | Porto Alegre - Vol. 26 - N..$^{\circ} 2$ - Maio / Agosto 2020 - p. 409-438. 


\begin{tabular}{|c|c|c|c|c|}
\hline Paulo & $\begin{array}{l}\text { CLT horista e } \\
\text { Pessoa Jurídica }\end{array}$ & $\begin{array}{c}\text { CLT horista, Pessoa Jurídica, } \\
\text { Autônomo (RPA) }\end{array}$ & 3 & 4 \\
\hline Fernando & $\begin{array}{l}\text { CLT mensalista } \\
\text { 40h e Pessoa } \\
\text { Jurídica }\end{array}$ & $\begin{array}{c}\text { CLT horista, CLT } \\
\text { mensalista, Pessoa Jurídica, } \\
\text { Autônomo (RPA) }\end{array}$ & 3 & 7 \\
\hline Manuel & $\begin{array}{l}\text { CLT mensalista } \\
\text { 20h, CLT horista } \\
\text { e Pessoa Jurídica }\end{array}$ & $\begin{array}{l}\text { CLT mensalista 20h, CLT } \\
\text { horista e Pessoa Jurídica }\end{array}$ & 3 & 6 \\
\hline Antonia & Pessoa Jurídica & $\begin{array}{c}\text { Pessoa Jurídica, Autônoma } \\
\text { (RPA) }\end{array}$ & 2 & 2 \\
\hline Luiz & CLT horista & $\begin{array}{c}\text { CLT horista, Pessoa Jurídica, } \\
\text { Autônomo (RPA) }\end{array}$ & 2 & 4 \\
\hline Norma & $\begin{array}{l}\text { Pessoa Jurídica e } \\
\text { Autônoma (RPA) }\end{array}$ & $\begin{array}{c}\text { CLT mensalista, Contrato } \\
\text { temporário (Lei no 8.745/93), } \\
\text { Autônoma (RPA), Pessoa } \\
\text { Jurídica }\end{array}$ & 4 & 7 \\
\hline Vera & $\begin{array}{l}\text { CLT horista e } \\
\text { Pessoa Jurídica }\end{array}$ & $\begin{array}{c}\text { CLT horista e Pessoa } \\
\text { Jurídica }\end{array}$ & 2 & 5 \\
\hline Ruben & $\begin{array}{l}\text { CLT mensalista } \\
\text { 20h e CLT horista }\end{array}$ & $\begin{array}{l}\text { CLT mensalista 20h, CLT } \\
\text { horista e Pessoa Jurídica }\end{array}$ & 2 & 4 \\
\hline Saul & $\begin{array}{l}\text { CLT horista e } \\
\text { Pessoa Jurídica }\end{array}$ & $\begin{array}{c}\text { CLT horista e Pessoa } \\
\text { Jurídica }\end{array}$ & 3 & 3 \\
\hline
\end{tabular}

O Quadro 2 também apresenta a concomitância de diferentes formas de contratação. $\mathrm{Na}$ maior parte dos casos, os/as entrevistados/as lecionavam em regime distinto em cada instituição, mas há situações em que vigoraram dois regimes diferentes na mesma IES. Isso ocorreu quando o/a docente lecionava na graduação e na pós-graduação lato sensu, e a IES possuía uma política de contratação para cada modalidade. Nesses casos, o/a professor/a recebeu por folha de pagamento (CLT) na graduação e por RPA ou PJ na pós-graduação.

Salienta-se que, com exceção de uma docente, todos/as os/as demais possuíam vínculo em mais de uma instituição na ocasião da entrevista. Nos relatos foram citadas, ao todo, vinte IESs privadas, sendo dez da região metropolitana de Porto Alegre, oito do interior e litoral do estado e duas do estado de Santa Catarina. No caso dos/as docentes horistas e/ou Pessoa Jurídica, observa-se um condicionamento em relação à oferta de aulas em mais de uma instituição de ensino para a composição do salário. Desta forma, os/as docentes desta modalidade contratual ministram aulas em duas ou mais instituições, trabalhando, muitas vezes, nos três períodos do dia.

Além de atuarem simultaneamente em mais de um local, muitos/as docentes relataram manter uma relação de sobreaviso com outras IESs, ou seja, quando necessário, essas outras instituições entram em contato para que seja ministrada uma disciplina específica. Esses casos são mais comuns na modalidade de pós-graduação lato sensu, quando a remuneração ocorre por RPA ou nota fiscal (PJ), tal como relata Fernando: “[...]eu estou há cinco anos dando aula (c) $(1) \Theta$ 
na -------, eu coordeno dois cursos do EAD e dou aula em dois cursos do presencial [...] E além disso eu dou aula pra cinco instituições quando me chamam pra pós, daí pro interior né, por PJ ou RPA".

Uma das grandes dificuldades apontada pelos/as entrevistados/as nesses casos é o curto prazo de antecedência entre o convite para ministrar a disciplina e seu início. Fernando, Norma, Paulo e Vera destacaram esse aspecto. Sobre a questão do curto prazo, Vera mencionou: "olha vou te dizer que $90 \%$ das vezes - não vou dizer que é $99 \%$ para ser mais comedida - mas $90 \%$ das vezes que a instituição chama, ela está com a corda no pescoço. Cursos de especialização são, via de regra, muito mal organizados".

Sem um vínculo formal, docentes vivenciam a perda de elementos importantes para a construção profissional, como segurança, autonomia e independência (IRIGARAY et al., 2019). Já que acostumar-se com a incerteza é obrigatório, a capacidade de estar sempre a postos também faz parte da experiência multiforme.

Trata-se da exaltação da flexibilidade e da capacidade de responder às exigências no curto prazo (SENNETT, 2006). Quando é o caso de substituição de outro/a docente, a questão torna-se ainda mais urgente, como narrou Norma:

\begin{abstract}
Esses dias um professor queria que eu substituísse ele na disciplina de Sociologia e Política e aí ele pediu assim 'ah tu tem algum conhecimento disso', e eu falei que não [...] Aí o que eu fiz, eu fui lá e apresentei um projeto em que eu trabalhei em parceria com o governo do estado e que promovia o desenvolvimento regional, e eu fui linkando. Não tinha nada pronto, porque eu fiquei sabendo de manhã e de noite eu dei aula. Só que é assim que funcionam as coisas. Aí quando eu vou substituir alguém da Administração, geralmente ela deixa mais ou menos o que ela quer que tu dê, assim. E eu fico sabendo no dia, aí eu dou uma lida, vou lá e dou aula e deu, sabe.
\end{abstract}

O relato de Paulo notabiliza outro elemento importante que é a multiplicidade de disciplinas ministradas, principalmente quando o/a docente está ingressando na carreira ou em uma IES. Movido pela expectativa de fazer parte do quadro fixo de docentes (IRIGARAY et al., 2019) torna-se imprescindível aceitar as "regras do jogo", comum a empresas privadas, em que é preciso ser produtivo para manter-se empregável (MEDEIROS; SIQUEIRA, 2019).

E aí ela me chamou e perguntou 'professor o senhor dá aula de Finanças?' e eu falei 'claro, eu dou da rebimboca da parafuseta, entendeu? Eu dou qualquer negócio para entrar nesse mundo'. E foi assim, eu fui chamado e comecei a dar aula [...] como a minha formação é muito eclética e as coordenações sentem que eu tenho uma certa segurança em sala de aula, eles me chamam para tudo. Então eu tenho 17 disciplinas dadas e prontas para a Instituição x, vai desde Projetos, passando por Finanças, por Pessoas, por Jogos Empresariais, por tudo que tu puder imaginar (Paulo). 
Sob a racionalidade neoliberal, as IES elegem como prioridade a sua rentabilização, o que abre espaço para a discussão sobre a qualidade da formação oferecida aos/às discentes. A adoção, por parte das IES privadas, do modelo empresarial de lucratividade no curto prazo e sua interferência na qualidade de ensino já foi discutida por Souza-Silva e Davel (2015). Os relatos de Norma e Paulo evidenciam uma realidade em que docentes ministram disciplinas que se distanciam da sua formação. Ademais, o acúmulo de diferentes disciplinas e o curto prazo para a preparação das aulas leva à adoção de estratégias, como a preparação de aulas que possam ser replicadas em diferentes turmas, cursos e IES.

Para aqueles/as que já possuem relação de forma sazonal com algumas IESs, a preocupação é de não perder o contato com a Instituição, o que, muitas vezes, significa aceitar disciplinas sob pressão, por receio de ser substituído/a (CALDERÓN, 2013). A informalidade torna uma figura historicamente prestigiada pelo conhecimento e pela capacidade de transformação social em uma commodity facilmente substituível (IRIGARAY et al., 2019).

No final de 2018/2 eu estava muito cansado, mas veio convites da -------- e eu justamente não disse não, mesmo estando muito sobrecarregado, justamente porque eu estava muito tempo sem dar aula lá, tu entende? Para não perder o vínculo. Aí eu queria ser lembrado lá, ser visto ainda, para não perder (Manuel).

A constituição de Pessoa Jurídica surge como uma escolha, como uma alternativa à alta incidência de tributação do RPA e, também, por imposição das IESs. Norma relatou que uma das instituições em que trabalhava passou a contratar novos/as docentes apenas por regime de pessoa jurídica, desde o ano de 2018. Destaca-se que a contratação de docentes como PJ foi facilitada pela Lei da Terceirização (13.429/17), que regulamentou a terceirização da "atividade fim" da empresa, que no caso das IESs privadas é a atividade de ensino.

[...] durante a noite eu era empregado - e sou até hoje - com carteira assinada, e aos sábados e domingos eu troquei de RPA pra MEI. Porque assim, eu tinha muita dificuldade de entrar por esse RPA porque nem as faculdades e nem a mim era bom, pela questão da tributação bem absurda, assim, por RPA. Então eu procurei um contador indicado por uma outra professora e ela me disse que ele era ótimo, assim, e foi (Paulo).

$\mathrm{Na}$ medida em que o management impõe sintonia com a lógica mercadológica, ao exaltar o empreendedorismo (ITUASSU; TONELLI, 2014), também se regozija na constituição de um Indivíduo S/A (GAULEJAC, 2007) que não só se entende como empresa, mas se vê também impelido a ser uma marca que ofereça um portifólio de produtos e serviços que possam atender ao mercado. Fernando, Saul e Antônia aproveitaram a tramitação para a abertura de cadastro de PJ e constituíram empresas individuais de pequeno porte para 
poderem incluir a prestação de outros serviços educacionais, como treinamentos e consultorias:

\begin{abstract}
Eu abri minha empresa já faz dois anos e eu não criei MEI porque, porque quando eu fui estudar pra criar o MEI eu pensei assim 'já que eu vou abrir uma empresa, eu vou colocar tudo que eu faço e tudo que eu posso vir a fazer'. E aí eu coloquei três atividades que é lecionar, produzir conteúdo e consultoria, que eu fiz já. Então eu abri uma empresa individual de pequeno porte, um passo acima do MEI, há 2 anos, e pago uma contadora. Uma taxa quando eu emito nota e outra quando eu não emito nota, todo mês. Por que isso? Por uma questão de segurança jurídica mesmo e por uma questão de valores, porque o RPA desconta muito. E o RPA [...] pode chegar a quase $30 \%$. Enquanto a pessoa jurídica tu tira ali o INSS e o IR e vai ficar ali 14 ou 15 , se não me engano (Fernando).
\end{abstract}

Duas questões particulares são evidenciadas nas entrevistas, no que se refere à precarização e sazonalidade do trabalho docente: a insegurança financeira e a impossibilidade de formação de vínculos/relações duradouras com discentes e com a IES empregadora (IRIGARAY et al., 2019). Essa insegurança é evidenciada na fala de Manuel:

Então de 2012 pra cá, sempre que essa disciplina era ofertada, em algum dos cursos, eu conduzia ela. Mas isso foi, digamos assim, fechada. Até porque eles dependem de fechar turmas, tanto até por agenda, e a ordem das disciplinas, se os alunos não têm algum problema de grade. Então é um ajuste que não é fácil. É interessante, por um lado, mas vou te dizer que pra mim é algo bem complicado, porque é algo que tu não pode depender, entende? Pelo menos não financeiramente (Manuel).

A fala de Manuel também colocou em evidência a individualização dos riscos provocados pela fragilidade do vínculo trabalhista (KREIN; COLOMBI, 2019). Já a dificuldade na construção de vínculos com a IES ficou ainda mais evidente no caso dos/as docentes que atuavam como celetistas, tal como expos Paulo:

\footnotetext{
Quando tu é MEI ou quando tu é RPA, tu tem uma relação completamente diferente com a instituição de ensino que tu teria se fosse empregado. O que mais bate em mim, assim, é como se eu fosse um terceirizado, assim. Eu não me envolvo na gestão, eu não me envolvo nas reuniões de planejamento do semestre. Eu sou chamado quando é preciso. Eu sou chamado, entro e dou aula, no máximo eu converso com o coordenador. E tem muita dificuldade para conseguir falar com a secretaria. Tem muita dificuldade de conseguir acesso a determinados sistemas. A gente não tem chave do sistema, então, assim, quando tu não é professor contratado - pelo menos essa é a minha realidade nas três faculdades que eu tenho relacionamento hoje MEI, antigo RPA - é, de ser um stranger [estranho] assim.
}

Paulo infere que se sente um trabalhador terceirizado, sem compreender, portanto, que a pejotização trata-se, justamente, de uma forma de terceirização. Ao constituir uma pessoa jurídica, o/a trabalhador/a pessoa física, presta seu serviço sem a incidência de qualquer direito trabalhista (ORBEM, 2016). A ideia de terceirização remete muitas vezes a um trabalho não especializado, pouco remunerado e mais fácil de ser substituído, o que contradiz o entendimento histórico de valorização da atividade docente. 
$\mathrm{Na}$ sua experiência como coordenador de curso, Ruben observa ainda mais essa inconstância dos vínculos e a dificuldade em compreender as rotinas processuais:

Eu vejo que, invariavelmente, nas instituições onde eu acompanhei programas de pós-graduação, justamente porque têm muitos professores convidados, né, o vínculo do professor acaba não sendo um vínculo muito profundo com o curso, né. Nem com os alunos assim. Porque é rápido, você acaba sendo vinculado àquela turma, aquele curso por um período curto de tempo. Se tu não é professor da instituição, é pior ainda, porque aí tu não conhece como é que funciona direito os processos.

Observa-se que a lógica da flexibilidade e da volatidade priva o/a docente da construção de uma carreira sólida, com perspectiva de longo prazo em uma área/instituição de ensino. As tarefas de pesquisa e extensão, fundamentais para o desenvolvimento da carreira docente, são impossibilitadas no modelo de pejotização. A constante mudança de disciplinas e instituições faz com que o presente se torne descontínuo com o passado (SENNETT, 1999), tudo ocorre no aqui e agora. A trajetória profissional em continuidade é substituída por um sentido de trabalho flexível, dividido em partes no curso da vida. Ademais, a inexistência de vínculos contínuos com as IESs contribui para o crescimento do processo de individualização profissional. Apesar de promulgada pelo discurso gerencialista (GAULEJAC, 2007) e pelo paradigma da flexibilidade (SENNETT, 1999; 2006), essa individualização potencializa a fragilização social (SOUZA, 2013), visto que isolados/as, esses/as profissionais se tornam mais vulneráveis ao entorno político, econômico e social.

Outra situação narrada sobre a contratação por PJ é a possibilidade de emitir nota pela empresa de outra pessoa, como no caso de Manuel: “[...] um pouco antes de entrar na eu fiz conteúdo pelo EAD. O pagamento foi por pessoa jurídica. A consultoria em que eu trabalhei, eu tenho uma relação muito boa com o dono da consultoria, e ele me permitiu usar as notas da empresa de consultoria”. Esta prática não é prevista legalmente, mas ocorre com frequência, visto que foi citada por três entrevistados/as.

A fala de Fernando sinaliza que mesmo no caso de docentes contratados/as no regime CLT, houve uma precarização do trabalho, principalmente no que se refere à sua intensificação, fato que já foi destacado por Ribeiro, Leda e Silva (2015). A redução no quadro de pessoal acarretou aumento na quantidade de turmas e, principalmente no caso do ensino EAD, no número de alunos/as:

De cinco anos pra cá mudou muito, porque teve redução de pessoal, demissões e aí a escolha não tá contigo, ainda mais quando tu coordena curso. Aí, é assim: 'encaixa e te vira'. Por exemplo, tinha lá a cadeira de 4 h do EAD, 4 h pra cada 250 alunos. Hoje é 4 h para cada 500 ou mais. Então por ter um contrato celetista turno integral $40 \mathrm{~h}$, muitas vezes não se escolhe. 
As demissões aumentaram a precariedade em uma realidade que já era de trabalho intensificado, o que indica a reconfiguração do trabalho docente com indícios de prática masoquista (IRIGARAY et al., 2019), marcada pela dualidade de prazer e sofrimento:

A ------- deu uma enxugada grande no pessoal de docência e de coordenação. E a nossa coordenadora, por exemplo, que saiu no início desse ano, ela coordenava toda a área de Negócios sozinha e lia pessoalmente todos os TCCs. Tu consegue calcular isso? Não é humanamente possível (Antonia).

Apesar disso, Fernando compreende que a atuação em locais diversos confere uma maior dinâmica e atualização à docência, revelando a naturalização ou negação de aspectos depreciativos (IRIGARAY et al., 2019) justificados em prol da inevitabilidade do discurso gerencial (MEDEIROS; SIQUEIRA, 2019).

\begin{abstract}
O lado bom é que tu consegue dar uma oxigenada, digamos, de ver uma outra instituição, uma outra realidade, um outro contexto, um outro tipo de aluno e eu acho que isso é bem bom pra construir a tua prática docente. Dar uma aula em Santa Cruz muda bastante de tu dar uma aula em Osório ou Erechim. Muda bastante, né. (Fernando).
\end{abstract}

A disposição ao risco é vista como positiva ao contribuir para o contínuo desenvolvimento de habilidades potenciais, uma das exigências do ideário profissional no paradigma da flexibilidade (SILVA, 2015). Norma também observa pontos positivos na flexibilidade proporcionada pela contratação como autônoma ou pessoa jurídica, em comparação à CLT:

Eu prefiro ser PJ porque tu ter vínculo com uma instituição particular, na graduação, por exemplo, tu tem que ir lá e bater ponto. Tu tem que ficar na instituição. Tu fica 40h e ganha x salário. Agora como PJ eu pego cinco pós e ganho 4x mais do que eu ganharia trabalhando em uma. Tem o outro lado que é não ter direitos, mas eu faço meu horário. Eu saio pra trabalhar $10 \mathrm{~h}$ da manhã. Eu faço meu doutorado e ninguém me cobra ponto porque eu sou PJ.

Por fim, as transformações observadas no trabalho docente de ensino superior trazem preocupações quanto às incertezas do futuro na carreira que, no capitalismo flexível, torna-se cada vez mais descontínua e firmada no curto prazo (SENNETT, 1999; 2006; 2015). Surgem casos como o de Anna, que nunca considerou prestar concurso público, mas as condições da docência no ensino privado, principalmente a insegurança quanto ao futuro, já a fazem pensar nessa possibilidade:

[...] eu me vejo dando aula, assim. E isso traz algumas angústias, porque a gente está vendo que o mercado docente também está ficando cada vez mais restrito. Recentemente, agora, a gente acompanhou demissão em massa [cita duas instituições]. Então, 'opa!', o mercado também... todas essas questões do ensino superior que estava sendo super valorizado agora tem um, como eu vou te dizer, um 
discurso, assim, que daqui a pouco vai pra beneficiar uma outra modalidade de educação, daqui a pouco não vão investir tanto mais no ensino superior.

Manuel cogita mudar-se para outro país, para fugir da precarização: "Um plano que eu tenho a curto prazo pros próximos anos é tentar fazer pós-doutorado fora [...] e o plano é já tentar ficar em uma instituição fora, até porque a nossa realidade no Brasil está bem complicada”. Já Norma e Paulo deixam claro que desejam ingressar em uma instituição federal de ensino. Ressalta-se que Norma se coloca em contradição nessa fala, tendo em vista que argumentou em favor da liberdade de trabalhar "sem vínculos", o que contraria a dedicação exclusiva prevista em instituições federais de ensino.

\footnotetext{
Olha, meu objetivo é entrar em uma instituição federal, porque eu acho que elas valorizam o professor e dão uma estabilidade e um salário que dificilmente tu atinge em uma universidade privada. Mas, ser professor está ficando bem complicado, porque tá tudo migrando pra EAD, as demissões são grandes, tu sente isso. As graduações pagam muito mal, eu sinceramente nem olho mais para graduação, por causa do valor (Norma).
}

Paulo, com formação em Comunicação Social, leciona na área de Administração, contudo, tendo em vista que grande parte dos concursos na área exige a graduação específica, decidiu cursar Administração pensando em seu futuro como docente. A rápida precarização observada no trabalho nas instituições de ensino privadas, principalmente no que se refere à instabilidade, é elencada como sua principal motivação para almejar uma carreira pública.

O modelo contratual precarizado, como observado por Calderón (2013), gera o sentimento ambíguo do prazer de trabalhar em sala de aula, em contraponto ao desânimo, desmotivação, desvalorização e precarização da profissão docente. "E eu sempre proporciono esses espaços pra eles, eu faço eles viajarem. E nessas viagens eu acho que a gente ganha muito, sabe? Por isso eu não quero sair da docência. E acho que nós ainda precisamos disso. Precisamos acreditar nisso" (Vera). A exemplo da conclusão do estudo de Passos e Freitas (2015), as entrevistas deste estudo evidenciaram que o trabalho é central nas vidas de docentes. Isto é, ele é visto como prazeroso, na medida em que os/as profissionais sentem que podem transformar vidas e ter uma influência positiva no futuro de discentes.

Por fim, no contexto da precarização do trabalho docente de ensino superior privado, surgem novas determinações ao exercício de suas funções. Uma delas é a responsabilização pela retenção de discentes, por meio de aulas que sejam consideradas atrativas. "Antes a minha disciplina era no início do semestre e eles diziam assim 'tua aula tem que ser tão apaixonante que os alunos digam essa é a pós que eu escolhi'” (Antonia). Como já antecipado 
por Alcadipani (2011), quando se estabelece uma relação de prestação de serviço no ensino, toda a lógica de formação e reflexão se desfaz, uma vez que estudantes são clientes, o/a docente deve atuar de forma quase teatral para que a satisfação com o produto (aula) seja atendida.

\section{CONSIDERAÇÕES FINAIS}

Este trabalho teve como objetivo analisar as atuais configurações de trabalho docente na área de Administração em instituições privadas de ensino superior, sobretudo da região metropolitana de Porto Alegre/RS. A multiformidade, que dá título ao artigo, refere-se às múltiplas formas de contratação, bem como de atuação, evidenciadas na carreira docente de ensino superior privado.

No caso de docente que atua como Pessoa Jurídica, não há relação de emprego e, como o contrato é interempresarial, não gera direitos trabalhistas e recolhimentos previdenciários. O/a profissional é quem assume a maior parte dos custos e dos riscos, visto que, caso não haja abertura de novas turmas por baixo número de matrículas, seu trabalho é dispensado pela instituição de ensino. Além desses fatores, a pejotização também contribui para o fortalecimento da ideia neoliberal da prevalência da autonomia e da vontade em detrimento da legislação trabalhista (ORBEM, 2016). Esta ideia neoliberal é reafirmada pela constituição de si como empresa, que individualmente, por conta e risco, deve estar sempre atualizada e pronta para entrar em cena (GAULEJAC, 2007; MEDEIROS; SIQUEIRA, 2019).

É este também o discurso sustentado pelo capitalismo flexível. Ancorando-se em Sennett (1999; 2006), observa-se que a lógica da flexibilidade priva o/a docente da construção de uma carreira sólida, com trajetória a longo prazo em uma área/instituição de ensino. A constante mudança de disciplinas e instituições faz com que o presente se torne descontínuo com o passado (SENNETT, 1999). A carreira linear pautada no longo prazo é substituída por um sentido de trabalho flexível, dividido em partes no curso da vida, em uma lógica de curto prazo.

Entre os resultados, destacam-se: a) concomitância de diferentes formas de contratação jurídica na carreira docente; b) simultaneidade de vínculo em diferentes IESs, de diferentes cidades; c) tendência à pejotização; d) insegurança financeira e dificuldade na formação de vínculos com discentes e instituições, devido à sazonalidade; e) relações de trabalho de curto 
prazo, pautadas na flexibilidade, por vezes percebida como vantajosa pelos/as entrevistados/as; e f) preocupação com a incerteza do futuro no trabalho.

Evidencia-se, a partir dos relatos, a primazia do curto prazo, principalmente nas instituições cuja relação é por trabalho autônomo ou contratação por pessoa jurídica. A flexibilidade e a volatidade revelam-se na exigência para que os/as docentes estejam sempre preparados para assumir diferentes disciplinas, sob a pena de enfraquecer ainda mais o seu vínculo com as IESs contratantes. No contexto do ensino superior e de pós-graduação privada, adaptabilidade, mobilidade e aceitação ao risco se sobressaem como condicionantes, principalmente no momento de ingresso nas trajetórias docentes observadas neste estudo.

Na perspectiva mercadológica, o ensino também é produto/serviço de valor agregado tanto na educação privada como na pública. Nesse sentido, a atividade docente se torna uma prestação de serviços sujeita à avaliação de resultados. Forma-se um discurso de exaltação dos conhecimentos adquiridos para além da academia, ou seja, obtidos no mercado - que tenham aplicabilidade econômica e ênfase na garantia da aprendizagem, bem como de uma performatividade inovadora. Cada docente é convocado/a a se tornar empreendedor/a de sua própria vida (GAULEJAC, 2007).

A adoção de princípios gerencialistas criou uma cultura performativa nas instituições de ensino, com um padrão de excelência sempre mutável. A ascensão de práticas pedagógicas inovadoras nos currículos escolares e nos discursos das instituições educacionais, aliada à responsabilização do/a docente pela empregabilidade futura de seus discentes, dão origem a uma concepção de docente empreendedor/a, inovador/a, móvel e adaptável às necessidades do mercado.

Nesse contexto, a qualidade do ensino superior se fragiliza em favor da rentabilização das IESs, pois os/as docentes passam a ter menos tempo para preparar as suas disciplinas ou até mesmo ministram disciplinas para as quais não estariam adequadamente habilitados/as. Afora isso, tendem a estar mais sobrecarregados, o que pode afetar o seu desempenho e até mesmo a sua saúde (HYPOLITO, 2011; IVO; HYPOLITO, 2015; RIBEIRO; LEDA; SILVA, 2015; RIBEIRO; LEDA, 2016; SANTOS et al., 2016). Questiona-se, assim: a favor de que $(\mathrm{m})$ a educação superior no ensino privado brasileiro está atuando? Que consequências o estímulo indiscriminado de educação à distância pode ocasionar para o futuro do trabalho docente? Esse modelo é capaz de gerar uma formação de ensino superior crítica e reflexiva? A partir desses questionamentos, sugere-se, portanto, conduzir uma pesquisa quantitativa, em nível nacional, para analisar as reconfigurações da carreira docente, tendo em vista a 
propagação de grupos educacionais privados no Brasil e as investidas para o enfraquecimento das instituições públicas.

Por fim, diante do cenário atual, destaca-se a necessidade emergente de estudos que discutam o trabalho docente de ensino superior privado no contexto da pandemia provocada pela COVID-19. A compulsoriedade da continuidade das aulas em instituições privadas em todos os níveis de ensino sinaliza um alerta para compreender os efeitos ocasionados por essas mudanças no cotidiano de docentes, as repercussões nas exigências de volatilidade, adaptabilidade e flexibilidade, bem como as variações contratuais precarizantes que são realizadas sob a justificava incontestável da pandemia. Conforme discutido neste artigo, a fragilização das relações de trabalho docente no ensino superior privado é evidenciada no trabalho como horista ou como pessoa jurídica, e tais vínculos tendem a se tornar mais frequentes diante do trabalho remoto emergencial. No contexto da COVID-19, essas formas de trabalho se dissipam e se tornam mais frequentes de modo veloz, ancorando confusos e incertos vínculos trabalhistas.

\section{REFERÊNCIAS}

ALCADIPANI, R. Academia e a Fábrica de Sardinhas. Organizações \& Sociedade, v. 18, n. 57, p. 346-348, 2011.

ALVES, G. A condição do proletariado: a precariedade do trabalho no capitalismo global. Bauru: Canal6, 2009.

Dimensões da precarização do trabalho: Ensaios de sociologia do trabalho.

Bauru: Projeto Editorial Praxis, 2013.

ANDERSON, G. Privatizando subjetividades: como a Nova Gestão Pública (NGP) está criando o "novo" profissional da educação. Revista Brasileira de Política e Administração da Educação, v. 33, n. 3, p. 593-626, 2017. https://doi.org/10.21573/vol33n32017.79297

ANDRADE, D. P.; OTA, N. K. Uma alternativa ao neoliberalismo: Entrevista com Pierre Dardot e Christian Laval. Tempo Social, v. 27, n. 1, p. 275-315, 2015. http://dx.doi.org/10.1590/0103-207020150115 
ANTUNES, R. A desertificação neoliberal no Brasil (Collor, FHC e Lula). Campinas: Autores Associados, 2004.

- Trabalho e reestruturação produtiva no Brasil neoliberal - precarização do trabalho e redundância salarial. Katálysis, v. 12, n. 9, p. 188-197, 2009. http://dx.doi.org/10.1590/S1414-49802009000200008

(Org.). Riqueza e miséria do trabalho no Brasil III. São Paulo: Boitempo Editorial, 2014.

O privilégio da servidão: o novo proletariado de serviço na era digital. São Paulo: Boitempo Editorial, 2018.

BAUER, M. W. Análise de conteúdo clássica, uma revisão. In: BAUER, WM. W.; GASKEL, G. (orgs.). Pesquisa qualitativa com texto, imagem e som: um manual prático. Rio de Janeiro: Vozes, 2015.

BECHI, D. As reformas da educação superior e as metamorfoses do trabalho docente na economia capitalista flexível. Rev. Inter. Educ. Sup., v. 3, n.1, p. 203-223, 2017. http://dx.doi.org/10.22348/riesup.v3i1.7733

BENDASSOLI, P. F. Público, privado e o indivíduo no novo capitalismo. Tempo Social, v. 12, n. 2, p. 203-236, 2000. DOI: http://dx.doi.org/10.1590/S0103-20702000000200014.

BRASIL. Instituto Nacional de Estudos e Pesquisas Educacionais Anísio Teixeira (Inep). Censo da Educação Superior 2018: notas estatísticas. Brasília, 2019.

LEI N 8.745, DE 9 DE DEZEMBRO DE 1993. Dispõe sobre a contratação por tempo determinado para atender a necessidade temporária de excepcional interesse público, nos termos do inciso IX do art. 37 da Constituição Federal, e dá outras providências. Disponível em: http://legislacao.planalto.gov.br. Acesso em: ago. 2019.

LEI N ${ }^{0}$ 5.890, DE 8 DE JUNHO DE 1973. Altera a legislação de previdência social e dá outras previdências. Disponível em: http://www.planalto.gov.br. Acesso em: ago. 2019 . 
LEI No 13.429, DE 31 DE MARÇO DE 2017. Altera dispositivos da Lei n $\stackrel{0}{6} 6.019$, de 3 de janeiro de 1974, que dispõe sobre o trabalho temporário nas empresas urbanas e dá outras providências; e dispõe sobre as relações de trabalho na empresa de prestação de serviços a terceiros. Disponível em: http://www.planalto.gov.br. Acesso em: ago. 2019.

LEI N 13.467, DE 13 DE JULHO DE 2017. Altera a Consolidação das Leis do Trabalho (CLT), aprovada pelo Decreto-Lei $\mathrm{n}^{\circ} 5.452$, de $1^{\circ}$ de maio de 1943, e as Leis n ${ }^{\circ} 6.019$, de 3 de janeiro de 1974, 8.036, de 11 de maio de 1990, e 8.212, de 24 de julho de 1991, a fim de adequar a legislação às novas relações de trabalho. Disponível em: http://www.planalto.gov.br. Acesso em: ago. 2019.

CALDERÓN, A. I. Terceirização do trabalho docente à luz da responsabilidade social do ensino superior. Trab. Educ. Saúde, v. 11, n. 3, p. 487-501, 2013. http://dx.doi.org/10.1590/S1981-77462013000300003.

COSTA, P. H. F.; GODOY, P. R. T. As marcas das metamorfoses do capitalismo contemporâneo e suas implicações no espaço geográfico: o caso do Wal-Mart. Revista Brasileira de Geografia Econômica, v. 1, n. 1, p. 1-12, 2012.

DARDOT, P.; LAVAL, C. A nova razão do mundo: ensaio sobre a sociedade neoliberal. São Paulo: Boitempo, 2016.

FERRER, W. M. H.; ROSSIGNOLI, M. Expansão do ensino superior e precarização do Trabalho docente: o trabalho do "horista" no ensino privado. Cadernos de Pesquisa, v. 23, N. Especial, 2016. DOI: http://dx.doi.org/10.18764/2178-2229.v.23n.especial/p106-118

FILGUEIRAS, V. A.; CAVALCANTE, S. M. Terceirização: debate conceitual e conjuntura política. Revista da ABET, v. 14, n. 1, 2015.

FONTOURA, L. R.; FONTOURA, V. R. Um Ensaio Acerca do Instituto da Quarteirização. Revista Eletrônica OABRJ, Rio de Janeiro, Edição Especial - Reforma Trabalhista, 2017. Disponível em: <http://revistaeletronica.oabrj.org.br/?artigo=um-ensaio-acerca-doinstitutoda-quarteirizacao>. Acesso em: 27 jan. 2020. 
GASKEL, G. Entrevistas individuais e grupais. In: BAUER, WM. W.; GASKEL, G. (orgs.). Pesquisa qualitativa com texto, imagem e som: um manual prático. Rio de Janeiro: Vozes, 2015.

GAULEJAC, V. de. Gestão como doença social: ideologia, poder gerencialista e fragmentação social. Aparecida: Ideias \& Letras, 2007.

GEMELLI, C. E. A quem serve a "neutralidade"? Análise do movimento escola sem partido à luz da ideologia gerencialista. Trabalho Necessário, v. 18, n. 35, p. 288-309, 2020. https://doi.org/10.22409/tn.v18i35.40509

GILDERSLEEVE, R. E. The neoliberal academy of the anthropocene and the retaliation of the lazy academic. Cultural Studies $\leftrightarrow$ Critical Methodologies, v. 17, n. 3, p. 286-293, 2017. https://doi.org/10.1177/1532708616669522

GUIMARÃES JUNIOR, S. D.; SILVA, E. B. A "reforma" trabalhista brasileira em questão: reflexões contemporâneas em contexto de precarização social do trabalho. Farol - Revista de Estudos Organizacionais e Sociedade, v. 7, n. 18, p. 117-163, 2020. https://doi.org/10.25113/farol.v7i18.5503

HYPOLITO, A. M. Reorganização gerencialista da escola e trabalho docente. Educação: Teoria e Prática, v. 21, n. 38, p. 1-18, 2011.

IRIGARAY, H. A. R.; OLIVEIRA, L. B.; BARBOSA, E. S. T.; MORIN, E. M. Vínculos profissionais e sentido do trabalho: uma pesquisa com professores do ensino superior. Revista de Administração Mackenzie, v. 20, n. 1, p. 1-27, 2019. http://dx.doi.org/10.1590/16786971/eRAMG190070

ITUASSU, C. T.; TONELLI, M. J. Sucesso, mídia de negócios e a cultura do management no Brasil. Cadernos EBAPE, v. 12, n. 1, p. 86-111, 2014. http://dx.doi.org/10.1590/S167939512014000100007

IVO, A. A.; HYPOLITO, A. M. Políticas gerenciais em educação: efeitos sobre o trabalho docente. Currículo sem Fronteiras, v. 15, n. 2, p. 365-379, 2015. 
JESSOP, B. On academic capitalism. Critical Policy Studies, v. 12, n. 1, p. 104-109, 2018. https://doi.org/10.1080/19460171.2017.1403342

KALFA, S.; TAKSA, L. Employability, managerialism, and performativity in higher education: a relational perspective. Higher Education, v. 74, p. 687-699, 2017. https://doi.org/10.1007/s10734-016-0072-2

KREIN, J. D.; COLOMBI, A. P. F. A reforma trabalhista em foco: desconstrução da proteção social em tempos de neoliberalismo autoritário. Educação \& Sociedade, v. 40, e0223441, p. 1-18, 2019. DOI: 10.1590/ES0101-73302019223441

\section{LAVAL, C. A escola não é uma empresa: o neoliberalismo em ataque ao ensino público.} São Paulo: Boitempo, 2019.

LOCATELLI, C. Os professores no ensino superior brasileiro: transformações do trabalho docente na última década. Revista Brasileira Estudos Pedagógicos, v. 98, n. 248, p. 77-93, 2017. http://dx.doi.org/10.24109/2176-6681.rbep.98i248.2815.

MAUÉS, O. C.; SOUZA, M. B. Precarização do trabalho do docente da educação superior e os impactos na formação. Em Aberto, v. 19, n. 97, p. 73-85, 2016. http://dx.doi.org/10.24109/2176-6673.emaberto.29i97.\%25p

NASCIMENTO, R. P.; SALVÁ, M. N. R. A política de avaliação da pós-graduação stricto sensu e o trabalho docente: Rumo ao "produtivismo acadêmico"? Encontro de Gestão de Pessoas e Relações de Trabalho da ANPAD, Brasília/DF, 2013.

OBSERVADOR. Grupo norte-americado Laureate vai vender universidades em Portugal, 2018. Disponível em: https://observador.pt/2018/08/24/grupo-norte-americano-laureate-vaivender-universidades-em-portugal/. Acesso em dez. 2019.

ORGANIZAÇÃO INTERNACIONAL DO TRABALHO (OIT). Relatório de Tendências Mundiais e Desemprego, 2017.

ORBEM, J. A (re)construção de uma "nova" modalidade de trabalho denominada “pejotização" no contexto sociocultural brasileiro. Áskesis, v. 5, n, 1, p. 143-156, 2016. 
PASSOS, J. C.; FREITAS, M. E. Sobre os sentidos do trabalho para "docentes móveis": Um estudo com professores de Administração. Encontro de Gestão de Pessoas e Relações de Trabalho da ANPAD, Salvador/ BA, 2015.

PENSIN, D. P. Docência na Educação Superior: empreendedorismo e a ordem do discurso. Retratos da Escola, v. 12, n. 23, p. 323-331, 2018. http://dx.doi.org/10.22420/rde.v12i23.850

RIBEIRO, C. V. S.; LEDA, D. B. O trabalho docente no enfrentamento do gerencialismo nas universidades federais brasileiras: repercussões na subjetividade. Educação em Revista, v. 32, n. 4, p. 97-117, 2016. http://dx.doi.org/10.1590/0102-4698161707.

RIBEIRO, C. V. S.; LEDA, D. B.; SILVA, E. P. A expansão da educação superior pública e suas implicações no trabalho docente. Revista Educação em Questão, v. 51, n. 37, p. 147174, 2015. https://doi.org/10.21680/1981-1802.2015v51n37ID7175

ROSS, S.; SAVAGE, L.; WATSON, J. University Teachers and Resistance in the Neoliberal $\begin{array}{lllll}\text { University. Labor } & \text { Studies } & \text { Journal, } & \text { p. } & 1-23,\end{array}$ http://dx.doi.org/10.1177/0160449X19883342

SANTOS, D. A. S.; AZEVEDO, C. A.; ARAÚJO, T. M.; SOARES, J. F. S. Reflexões sobre a saúde docente no contexto de mercantilização do ensino superior. Revista Docência Ensino Superior, v. 6, n. 1, p. 159-186, 2016. https://doi.org/10.35699/2237-5864.2016.2105

SENNETT, R. A Corrosão do caráter: consequências pessoais do trabalho no novo capitalismo. Rio de Janeiro: Record, 1999.

SENNETT, R. O novo espírito do capitalismo. Rio de Janeiro: Record, 2006.

SENNETT, R. Juntos: Os rituais, os prazeres e a política da cooperação. Rio de Janeiro: Record, 2015.

SEVERO, R. G.; FLECK, C. Instituições privadas de ensino superior no rio grande do sul: organização flexível e situações atuais do trabalho docente. Germinal: Marxismo e Educação em Debate, v. 9, n. 1, p. 96-106, 2017. http://dx.doi.org/10.9771/gmed.v9i1.18096

SILVA, R. R. D. Sennett \& a Educação. Belo Horizonte: Autêntica, 2015.

(c) $(1) \Theta$ REAd | Porto Alegre - Vol. 26 - N. ${ }^{\circ} 2$ - Maio / Agosto 2020 - p. 409-438. 
SOUZA-SILVA, J. C.; DAVEL, E. Concepções, práticas e desafios na formação do professor: examinando o caso do ensino superior de Administração no Brasil. Organizações \& Sociedade, v.12, n.35, 2005. http://dx.doi.org/10.1590/S1984-92302005000400007

SOUZA. A. N. Relações de trabalho docente: emprego e precarização do trabalho. In: PINO, I.R.; ZAN, D. D. P. Plano Nacional da Educação (PNE): questões desafiadoras e embates emblemáticos. Brasília-DF: INEP, 2013.

(c) $\left(\right.$ (1) $\Theta$ REAd | Porto Alegre - Vol. 26 - N. ${ }^{\circ} 2$ - Maio / Agosto 2020 - p. 409-438. 